\title{
An Analysis of Influential Factors of Brand Equity and Its Impact on Consumer Buying Decision-The Selected Branches of Mellat Bank in Bushehr City as Case Study
}

\author{
Ali Kazemi, PHD \\ University of Isfahan, Iran \\ E-mail: alik@ase.ui.ac.ir
}

Seyed Yaghoub Hosseini, PHD

Persian Gulf University, Iran

E-mail: hosseini@pgu.ac.ir

\author{
Mahboubeh Moradi, MA \\ University of Isfahan, Iran \\ "Corresponding Author" \\ E-mail: Mahboubeh.67@gmail.com
}

DOI: 10.6007/IJARBSS/v3-i11/354 URL: http://dx.doi.org/10.6007/IJARBSS/v3-i11/354

\begin{abstract}
This study analyzes the influence factors of brand equity and its impact on consumer buying decision in The Selected Branches of Mellat Bank in Bushehr City. Questionnaires were designed to measure variables of study. The samples were selected randomly. Also, SPSS and Amos software were used to analyze data and test hypotheses. The results indicate that buying decision of Melat costumers Influenced by Brand equity. Also, Brand equity influenced by Personnel and Place of distribution as marketing mix.
\end{abstract}

Keywords: Brand, Brand equity, Customer Based Brand Equity, Personnel, Place of Distribution and Consumer Behavior.

\section{Introduction}

Today, one of the most popular and most important marketing concepts is brand equity. There are a number of reasons for its popularity but its strategic role in the gaining competitive advantage is one of the most important researches. An appropriate metric, for the evaluation of long run impact of the marketing decisions can be acquired by measuring brand equity correctly and objectively (Simon and Sullivan, 1993). To be successful, a firm should retain its current customers and make them loyal to their brands (Dekimpe et al., 1997: 405). More buying, paying premium prices and providing new referrals through positive word of mouth, loyal customers build businesses (Ganesh et al., 2000: 65). For this reason, knowing how consumers assess a brand is important. Therefore, we need to determine the factors of 
marketing mix which affect to brand equity and brand equity influences on consumer buying decision.

Brand equity refers to the incremental utility or value added to a product from its brand name. It is often believed to contribute to a company's long-term profitability (Jalilvand et al, 2011). Brand equity has been deemed as primary capital for many industries. Strong brands can increase customers' trust in the produce or service purchased and enabling them to better visualize and understand intangible factors. According to Yoo and Donthu (2001), brand image can influence a company's future profits and long-term cash flow, a consumer's willingness to pay premium prices, merger and acquisition decision making, stock prices, sustainable competitive advantage, and marketing success. Brand equity, when correctly and objectively measured, is the appropriate metric for evaluating the long-run impact of marketing decisions (Simon and Sullivan, 1993). Positive customer-based brand equity, in turn, can lead to greater revenue, lower costs, and higher profits; and it has direct implications for the firm's ability to command higher prices, customers' willingness to seek out new distribution channels, the effectiveness of marketing communications, and the success of brand extensions and its opportunities (Keller, 2003).

The operationalizations of customer-based brand equity can be divided into consumer perception (e.g. brand awareness and brand associations, perceived quality) and customer behavior (e.g. brand loyalty, willingness to pay a high price). Also, Aaker (1996) develop a framework for studying Components of brand equity from the customer perspective and suggest that consumers' brand image contribute to the meaning or value of a brand. Brand equity then influences consumer buying decision, and ultimately Brand equity is influenced by marketing mix such as, advertising, personnel, place of distribution and ... which are discussed in following. In this study, we determine the effect of Personnel, distribution as variables of marketing mix on brand equity of Melat bank in Bushehr city. Additionally, the study is extended to investigate the relationship between brand equity and consumer buying decision of Melat bank in Bushehr city.

\section{A Review of the theoretical literature Brand Equity}

Brand equity is a multi-dimensional concept and a complex phenomenon, some dimensions of which have been empirically tested in the literature. Among several brand equity models in the literature, we have chosen that constructed by Aaker (1991) because of the popularity of this model in branding research. It has been probed in a number of empirical investigations (Eagle and Kitchen, 2000; Yoo et al., 2000; Faircloth et al., 2001; Washburn and Plank, 2002; Atilgan et al., 2005; Pappu et al., 2005; Kayaman and Arasli, 2007; Chen and Chang , 2008), the most critical parts of which involve the verification of the dimensions on which brand equity is based. They developed a multidimensional, customer-based brand equity scale using Aaker's (1991) four theoretically defined dimensions and one dimensions of brand equity model of Keller (1996). In developing our conceptual model (shown in Figure 1), we review the literature on Brand loyalty, Brand awareness and associations, Perceived service quality and Brand image.

1. Brand loyalty: The most challenging part of conducting a brand loyalty research is to define the brand loyalty construct and its measurement. The amount of purchases of a 
particular brand is the basis for behavioral perspective, while consumer dispositions and preferences towards that particular brand provide the basis for attitudinal perspective. Factors that can/may influence choices or the reasons for purchases are considered the vital focus regarding the choice perspective. Brand loyalty has also been defined by Aaker (1991) as the likelihood of a customer to switch over to another brand, especially, when the other brand is different in product features or price. Keller (2003), however, scrutinizes brand loyalty as the relationship between the customer and the brand. The aforementioned definitions tend to point out a relationship among brand equity and brand loyalty. This satisfaction further leads towards the trust in enhancing loyalty of the customers (haq et al., 2011).

2. Brand awareness: In marketplace, brands possess different amount of value and power. At one extreme, there are brands which are unknown to most of the customers. While on the other entrance, there are certain brands which are well known among the customers. "Brand awareness as defined by Aaker (1991), is the ability of potential user to recall and recognize that a certain brand is a member of certain product category." Keller (2003) argues that brand awareness plays a vital role in the process of purchase intention and decision making by the help of three advantages and they are choice of advantages, consideration advantages and learning advantages. High level of brand awareness causes customer-based brand equity when the consumer holds strong and favorably unique brand associations in his/her memory.

3. Brand associations: According to Aaker (1991: 101) "anything which is linked in memory to a brand" is known as brand associations. Brand associations can be seen in many forms and it reflects product characteristics that are independent of product itself (Chen, 2001). Rio et al. (2001) emphasizes the importance of brand associations, for example, in gaining competitive advantage. Brand associations lay down the basis for purchase intentions that eventually affects brand loyalty. This creates values for both firms and the customers. These benefits have been listed by Aaker (1991) as follows: brand differentiation, purchase intentions generation, creation of positive attitudes with the help of relative information and provides a support for further extension. Therefore, it is now prudent to say that, strong positive brand associations with a brand enhance its brand equity.

In this research these 2 variables considered together, because their influence on consumer buying decision is the same.

4. Perceived service quality: Zeithmal (1988) defines perceived service quality as "the perception of a customer about the overall quality of a service or product with respect to its intended purpose, relative to its alternatives." To stay competitive, many companies have turned to customer-driven quality and they are using this strategy as a potent strategic weapon. These companies are satisfying customers consistently and profitably by fulfilling customer needs and wants as well as, preferences of quality. The intimate connection among services and product quality, customer satisfaction and profitability of company has become the main focus after it was identified by Kotler (2000). 
5. Brand image: According to a customer-based brand equity perspective of Keller (1996), the indirect approach to measuring brand equity attempts to assess potential sources for brand equity by measuring consumer mindset or brand knowledge. The indirect approach is useful in identifying what aspects of the brand knowledge may potentially cause the differential response that creates brand equity in the marketplace. Because any one measure typically only captures one particular aspect of brand knowledge, multiple measures need to be employed to account for the multi 4dimensional nature of brand knowledge: Brand awareness can be assessed through a variety of aided and unaided memory measures that can be applied to test brand recall and recognition; brand image can be assessed through a variety of qualitative and quantitative techniques.

\section{Marketing Mix}

The "Marketing Mix" is a term used to describe the combination of tactics used by a business to achieve its objectives by marketing its products or services effectively to a particular target customer group. It is also referred to as the '4Ps'-Product, Price, Promotion and Place, or the '7Ps'- the 4Ps with the addition of People, Process and Physical Evidence, also called the extended marketing mix.

1. Product: Marketing is about identifying, anticipating and satisfying customer needs. You need to be sure that your products and services continue to meet your customers' needs.

2. Place: 'place' is the means of distribution you select depending on the type of product or service you are marketing. Your choice will impact on your pricing and your promotion decisions.

3. Price: Price generates profit so is an important element of the mix.

4. Promotion: The promotional mix is made up of 5 elements: advertising, sales promotions, public relations, direct marketing, personal selling. The combination of tools you use depends on the budget you make available, the message you wish to communicate and the group of customers you are targeting.

5. Process: The process involved in delivering your products and services to the customer have an impact on the way in which your customers perceive you.

6. People or Personnel: The people you employed in your organization will determine the quality of service your customers receive. Happy, Skilled and motivated staff make happy customers. They are more likely to think about the customer and deliver good customer service if they are well trained and are recruited for their positive attitude to customers.

7. Physical Evidence: Physical Evidence is a term used to describe the type of image that your business portrays through its physical presence, namely its premises, the appearance of its staff, its vehicles, etc.

In this study, 2 variables of marketing mix, Place and people, are considered.

\section{Consumer Buying Decision}

Buying Behavior is the decision processes and acts of people involved in buying and using products. Need to understand:

Why consumers make the purchases that they make?

What factors influence consumer purchases? 
The changing factors in our society.

Consumer Buying Behavior refers to the buying behavior of the ultimate consumer. A firm needs to analyze buying behavior for:

Buyer's reactions to a firms marketing strategy has a great impact on the firm's success. The marketing concept stresses that a firm should create a Marketing Mix (MM) that satisfies (gives utility to) customers, therefore need to analyze the what, where, when and how consumers buy. Marketers can better predict how consumers will respond to marketing strategies. Six Stages to the Consumer Buying Decision Process (For complex decisions). Actual purchasing is only one stage of the process. Not all decision processes lead to a purchase. All consumer decisions do not always include all 6 stages, determined by the degree of complexity...discussed next.

The 6 stages are:

1. Problem Recognition(awareness of need)--difference between the desired state and the actual condition. Deficit in assortment of products. Hunger--Food. Hunger stimulates your need to eat. Can be stimulated by the marketer through product information--did not know you were deficient?

2. Information search--

- Internal search, memory.

- External search if you need more information. Friends and relatives (word of mouth). Marketer dominated sources; comparison shopping; public sources etc.

3. Evaluation of Alternatives--need to establish criteria for evaluation, features the buyer wants or does not want. Rank/weight alternatives or resume search.

4. Purchase decision--Choose buying alternative, includes product, package, store, method of purchase etc.

5. Purchase--May differ from decision, time lapse between 4 and 5, product availability.

6. Post-Purchase Evaluation--outcome: Satisfaction or Dissatisfaction. Cognitive Dissonance, have you made the right decision. This can be reduced by warranties, after sales communication etc (Dacko, 2008).

According to the theoretical literature, the hypotheses of this research are:

H1- Personnel influences brand equity of Melat bank in Bushehr city.

$\mathrm{H} 2$ - Place of Distribution influences brand equity of Melat bank in Bushehr city.

H3- Brand Equity influences costumer purchase intention of Melat bank in Bushehr city.

Considering available theoretical literature in the study and mentioned hypotheses, the conceptual model of this research is shown in figure 1. 


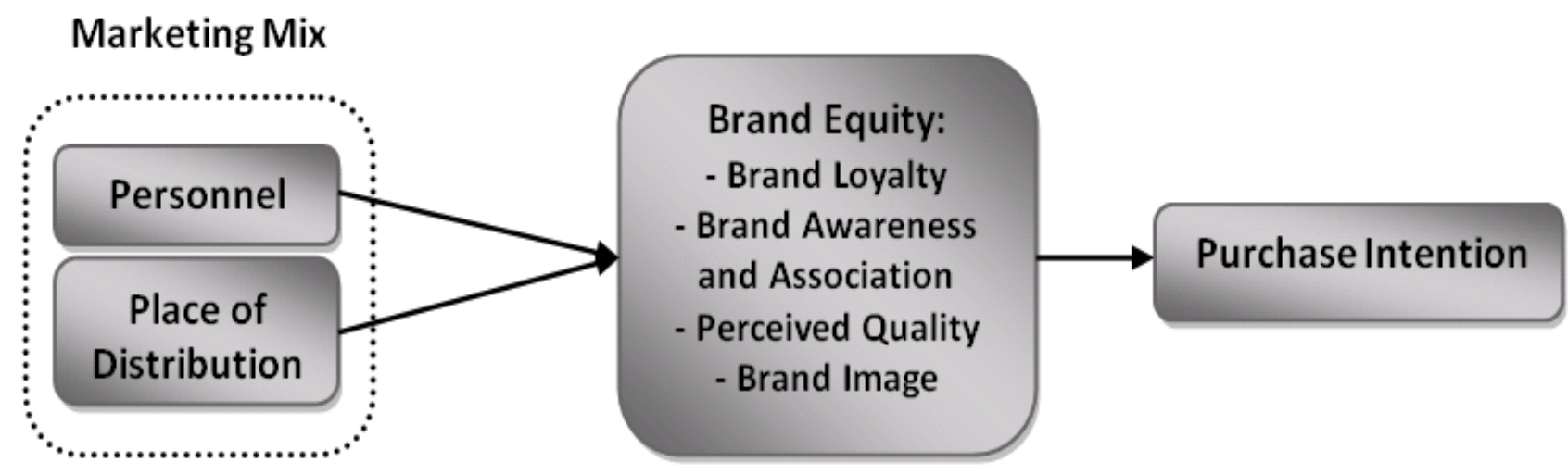

Figure 1: Research Conceptual Model

\section{Research Methodology \\ Research Population and Sample}

This research, from the viewpoints of practical purposes and methods of data collection is a descriptive survey research. The research's statistical population is customers of Melat banks in Bushehr city that are available at the time of data collection. For data collection, based on the subject's literature, a questionnaire was designed. 310 questionnaires were distributed randomly among customers of Melat banks in Bushehr city. The questionnaires used in this study had two parts. The first part included demographic variables such as gender, age and educational level and the second part was devoted to measure this research's considered variables. Rating scale for each question was prepared based on a score of 1 to 5 that is from very agreeing to strongly disagree.

\section{Research Variables Measurement}

Content validity of this questionnaire was approved by Isfahan University authorities and professors. Cronbach's alpha was used to determine the reliability of the test. For this purpose, an initial sample of 50 questionnaires was distributed. By using obtained data, Cronbach's alpha was calculated. Cronbach's alpha for all the questions related to the variables in the research analytical model was calculated as $0.931 \%$ which is acceptable. Criteria used in evaluating research variables are shown in Table 1.

\section{Analytical Findings of the Research Conceptual Model}

In the first step, measurement models get fitted. Models' fit indexes are listed in Table 1: 
Table 1: overall indexes of fit in measurement models

\begin{tabular}{|c|c|c|c|c|c|c|c|}
\hline $\begin{array}{c}\text { Variables } \\
\text { Indexes }\end{array}$ & $\begin{array}{c}\text { Personn } \\
\text { el }\end{array}$ & $\begin{array}{c}\text { Place of } \\
\text { Distributio } \\
\mathbf{n}\end{array}$ & $\begin{array}{c}\text { Brand } \\
\text { Loyalty }\end{array}$ & $\begin{array}{c}\text { Brand } \\
\text { Awareness and } \\
\text { Association }\end{array}$ & $\begin{array}{c}\text { Perceive } \\
\mathbf{d} \text { Quality }\end{array}$ & $\begin{array}{c}\text { Brand } \\
\text { Image }\end{array}$ & $\begin{array}{c}\text { Purchase } \\
\text { Intentio } \\
\mathbf{n}\end{array}$ \\
\hline CMIN/DF & 2.99 & - & 3.07 & - & - & 1.9 & 1.21 \\
\hline RMR & 0.01 & 0.000 & 0.012 & 0.000 & 0.000 & 0.006 & 0.009 \\
\hline GFI & 0.97 & 1.000 & 0.995 & 1.000 & 1.000 & 0.99 & 0.99 \\
\hline AGFI & 0.93 & - & 0.965 & - & - & 0.98 & 0.98 \\
\hline IFI & 0.97 & 1.000 & 0.997 & 1.000 & 1.000 & 1.000 & 0.99 \\
\hline NFI & 0.97 & 1.000 & 0.996 & 1.000 & 1.000 & 0.99 & 0.99 \\
\hline CFI & 0.98 & 1.000 & 0.997 & 1.000 & 1.000 & 1.000 & 0.99 \\
\hline
\end{tabular}

Measurement models have a good fit, in other words, overall indexes confirm that models are clearly supported by data. Variables' loading factor, as the most important fit index, has been considered in the consumer attitude model and is widely used in results' interpretation. The questions loadind factors are mentioned in appendix.

The Results of Structural Equation Modeling Analysis

After evaluating and verifying the measurement models in the first step, in the second step, to test hypotheses, structural equation model is fitted and analyzed. Overall indexes of models fitness are presented in Table $2 \& 3$.

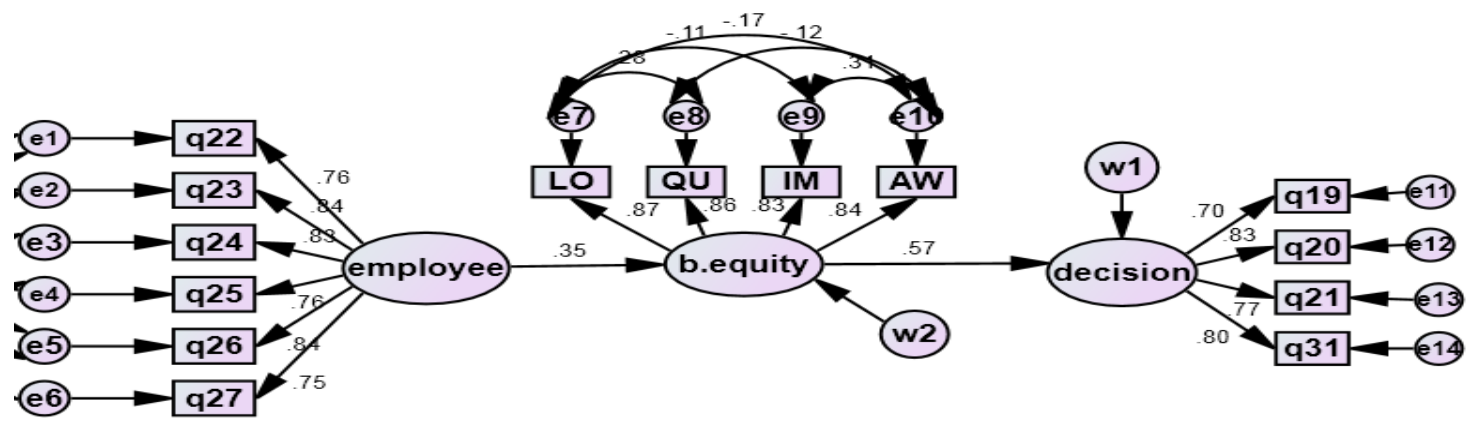

Figure 2: Structural Equation Modeling Analysis 1

Table 2: model 1 fitness indexes

\begin{tabular}{|c|c|c|c|c|c|c|c|}
\hline$R M R$ & $I F I$ & $C F I$ & $N F I$ & $A G F I$ & $G F I$ & $R M S E A$ & $C M I N / d f$ \\
\hline 0.03 & 0.96 & 0.96 & 0.94 & 0.945 & 0.93 & 0.07 & 2.87 \\
\hline $\begin{array}{c}\text { Close } \\
\text { to zero }\end{array}$ & $0.90>$ & $0.90>$ & $0.90>$ & $0.90>$ & $0.90>$ & $0.08<$ & $\begin{array}{c}1> \\
3<\end{array}$ \\
\hline
\end{tabular}




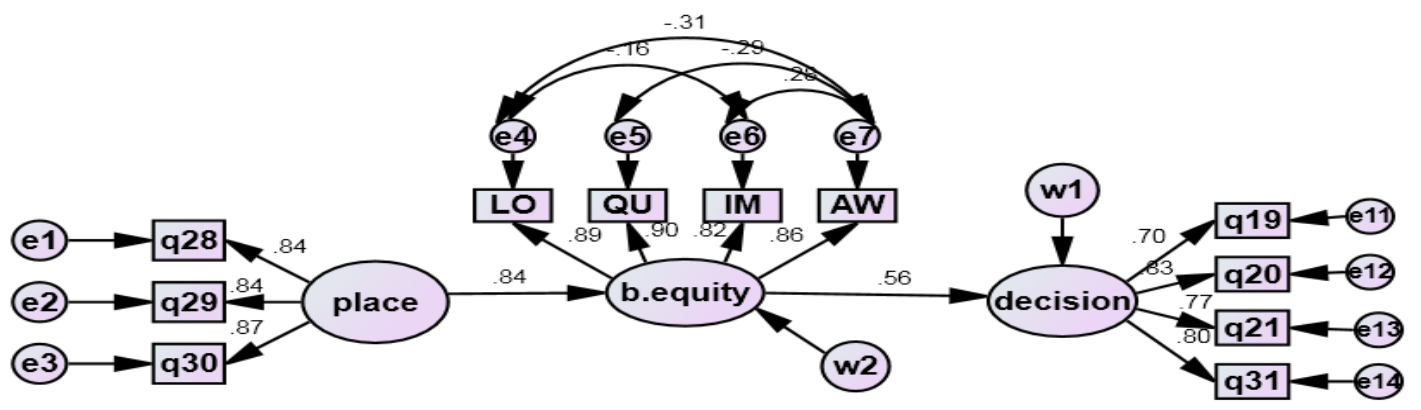

Figure 3: Structural Equation Modeling Analysis 2

Table 3: model 2 fitness indexes

\begin{tabular}{|c|c|c|c|c|c|c|c|}
\hline$R M R$ & $I F I$ & $C F I$ & $N F I$ & $A G F I$ & $G F I$ & $R M S E A$ & $C M I N / d f$ \\
\hline 0.06 & 0.96 & 0.97 & 0.95 & 0.945 & 0.94 & 0.07 & 2.73 \\
\hline $\begin{array}{c}\text { Close } \\
\text { to zero }\end{array}$ & $0.90>$ & $0.90>$ & $0.90>$ & $0.90>$ & $0.90>$ & $0.08<$ & $\begin{array}{c}1> \\
3<\end{array}$ \\
\hline
\end{tabular}

Results obtained from the information provided in Table $2 \& 3$ are as follow:

Amos output results in estimating the standard model indicates that path analysis model 2 are appropriate model. The normal Chi-square value is 2.87 which stand between two values of 1 and 3. RMSEA value is 0.07 which is appropriate, also the values of GFI, AGFI, NFI, CFI and IFI are all above 90\%; and finally RMR value is close to zero. All the values of model fitness indexes are in the reception area and these indexes indicate that model has a goodness-of-fit which is obtained by data and model is well supported by collected data.

And also, Amos output results in estimating the standard model indicates that path analysis model 3 are appropriate model. The normal Chi-square value is 2.73 which stand between two values of 1 and 3. RMSEA value is 0.07 which is appropriate, also the values of GFI, AGFI, NFI, CFI and IFI are all above 90\%; and finally RMR value is close to zero. All the values of model fitness indexes are in the reception area and these indexes indicate that model has a goodnessof-fit which is obtained by data and model is well supported by collected data.

Hypotheses and regression coefficients as well as partial indexes values for each hypothesis are shown in table 5 . Research's final model is presented in the appendix.

Table 4: hypotheses testing results

\begin{tabular}{|l|c|c|c|c|c|}
\hline \multicolumn{1}{|c|}{ Hypotheses } & $\begin{array}{c}\text { Sample } \\
\text { size }\end{array}$ & $\begin{array}{c}\text { Significance } \\
\text { number }\end{array}$ & $\begin{array}{c}\text { Corroboration } \\
\text { coefficient }\end{array}$ & $\begin{array}{c}\text { Critical } \\
\text { ratio }\end{array}$ & $\begin{array}{c}\text { Test } \\
\text { result }\end{array}$ \\
\hline Personnel $\rightarrow$ Brand equity & 300 & 0.000 & 0.35 & 5.42 & $\begin{array}{c}\text { accepte } \\
\text { d }\end{array}$ \\
\hline Place of Distribution $\rightarrow$ Brand equity & 300 & 0.000 & 0.83 & 15.32 & $\begin{array}{c}\text { accepte } \\
\text { d }\end{array}$ \\
\hline Brand equity $\rightarrow$ Purchase intention & 300 & 0.000 & 0.57 & 7.02 & $\begin{array}{c}\text { accepte } \\
\text { d }\end{array}$ \\
\hline
\end{tabular}


In the significance level of 0.05 , if the table's significance number is smaller than 0.05 , relationship between each pair of variables is confirmed.

\section{Discussion and Conclusion}

As it is perceived from the results in Table 4, it can be concluded that Personnel and Place of Distribution has diluted brand image but this dilution, when the extension is applied to a dissimilar product is more tangible. Also, the following results were obtained through testing hypotheses:

H1- Personnel influences brand equity of Melat bank in Bushehr city.

Based on testing research hypotheses and the Sig of this relationship which is less than 0.05 , it can be said that Personnel, with a certainty of $95 \%$, positively influences brand equity of Melat bank in Bushehr city. As expected, customer-based brand equity is a valuable asset for any services sector, especially for marketing managers to assess the results of their efforts by getting feedback from customers to diagnose any problem that can appear in the provided service. This should enable managers to minimize problems that could arise from personnel.

$\mathrm{H} 2-$ Place of distribution influences brand equity of Melat bank in Bushehr city.

Based on testing research hypotheses and the Sig of this relationship which is less than 0.05, it can be said that Place of distribution, with a certainty of $95 \%$, positively influences brand equity of Melat bank in Bushehr city. As expected, customer-based brand equity is a valuable asset for any services sector, especially for marketing managers to assess the results of their efforts by getting feedback from customers to diagnose any problem that can appear in the provided service. This should enable managers to minimize problems that could arise from limited resources.

H3- Brand Equity influences consumer buying decision of Melat bank in Bushehr city.

Based on testing research hypotheses and the Sig of this relationship which is less than 0.05, it can be said that brand equity, with 95 percent of certainty, positively influence costumer purchase intention of Melat bank in Bushehr city. In fact, when there is strong brand equity, consumer attitude to the brand will be more favorable, because consumers excessively trust in a strong brand and decide to purchase it. This research's result is in line with the results of Eagle and Kitchen, 2000; Yoo et al., 2000; Faircloth et al., 2001; Washburn and Plank, 2002; Atilgan et al., 2005; Pappu et al., 2005; Kayaman and Arasli, 2007; Chen and Chang, 2008. According to Keller (2003), brand awareness plays an important role in consumer decision making by bringing three advantages; these are learning advantages, consideration advantages, and choice advantages. Brand associations represent basis for purchase decisions and also create value to the firm and its customers. Aaker (1991) has listed benefits of brand associations as follows: helping to process/retrieve information, differentiating the brand, generating a reason to buy, creating positive attitudes/feelings, and providing a basis for extensions. Similar to brand associations, perceived quality also provides value to consumers by providing them with a reason to buy and by differentiating the brand from competing brands. According to the 
literature, while the definitions of brand loyalty based on the attitudinal perspective emphasized consumer intentions to be loyal to the brand, the definitions based on a behavioral perspective accentuated consumer's actual loyalty to the brand as reflected in purchase intention. Thus, we conceptualize brand loyalty based on a behavioral perspective and brand image.

In this study, an analysis of influence factors of brand equity and its impact on consumer buying decision in Mellat bank in Bushehr city has been the subject of discussion. According to the results, this study not only reveals the effects of brand equity on consumer buying decision, but also shows effects of personnel and place of distribution as marketing mix on brand equity and consumer buying decision.

This study was conducted in Iran, Bushehr and among customers of Melat bank. Thus, its extension to other countries and provinces is limited because different cultures may lead to different results.

Another limitation is related to the variables used in the study. Although other variables of marketing mix such as advertisement can also be effective on brand equity, in this study only some variables such personnel and place of distribution were evaluated.

As a result, this study has not considered all the variables existed in brand equity, that this issue influences research's results. Future researchers should investigate more market conditions to find whether validated relationships still remain under the effect of other variables (such as, marketing mix, competition actions, etc).

For validation, researchers can use the research model in the field of other products. Also, this study can be applied to other countries and provinces with different cultures. Researchers can examine such variables as brand identity, brand meaning, brand responses and finally brand relationships as components of brand equity.

\section{References}

Aaker, D.A. (1991). "Managing Brand Equity". The Free Press, New York, NY. Aaker, D.A. (1996). "Building Strong Brands". The Free Press, New York, NY.

Atilgan, E., Aksoy, S. and Akinci, S. (2005). "Determinants of the Brand Equity: A Verification Approach in the Beverage Industry in Turkey". Marketing Intelligence \& Planning, 23(3), 237248.

Chen, A.C. (2001). "Using Free Association to Examine the Relationship between the Characteristics of Brand Associations and Brand Equity". Journal of Product \& Brand Management, 10(6/7), 439-49.

Dako, S. G., (2008). The advanced dictionary of marketing, $1^{\text {st }}$ Ed. Oxford University Press Inc., 65- 119.

Eagle, L. and Kitchen, P. (2000). Building brands or bolstering egos? A comparative review of the impact and measurement of advertising on brand equity. Journal of Marketing Communications, 6 (2), 91-106.

Faircloth, J.B., Capella, L.M. and Alford, B.L. (2001). "The Effect of Brand Attitude and Brand Image on Brand Equity". Journal of Marketing Theory \& Practice, 9(3), 61-75.

Haq, J. U., Ijaz, A., and Mehmood, S. (2011). "The Influence of Customer Orientation on Customer Relationship in Telecom Services", Information Management and Business Review, 222-227. 
Jalilvand, Mohammad Reza., Samiei, Neda., Mahdavinia, Seyed Hessamaldin. (2011). " The Effect of Brand Equity Components on Purchase Intention: An Application of Aaker's Model in the Automobile Industry". International Business and Management. 2(2), 149-158.

Kayaman, R. and Arasli, H. (2007). "Customer Based Brand Equity: Evidence from the Hotel Industry". Managing Service Quality, 17(1), 92-109.

Keller, k.l. (1993). "Conceptualizing, measuring, and managing customer-based brand equity". Journal of Marketing. 57 (1). Pp.1-22.

Keller, K.L. (2003). "Strategic Brand Management: Building, Measuring and Managing Brand Equity", 2nd ed., NJ: Prentice-Hall.

Kotler, P. (2000). "Marketing Management: Analysis, Planning, Implementation and Control", 10th ed., Prentice-Hall, Englewood Cliffs, NJ.

Pappu, R., Quester, P. G. and Cooksey, R. W. (2005). "Consumer-Based Brand Equity: Improving the Measurement - Empirical Evidence". Journal of Product \& Brand Management, 14(3), 143154.

Rio, A., Vazquez, R. and Iglesias, V. (2001), "The role of the brand name in obtaining differential advantages", J. of Product and Brand Manage. 10(7), 452-65

Simon C Sullivan M. (1993). "The Measurement and Determinants of Brand Equity: A Financial Approach". Marketing Science, 12(1). 28-52.

Washburn, J.H. and Plank, R.E. (2002). "Measuring Brand Equity: An Evaluation of a consumerBased Brand Equity Scale". Journal of Marketing Theory \&Practice, 10(1), 46-61.

Yoo, B., Donthu, N., (2001). "Developing and validating a multidimensional customer-based equity scale". Journal of Business Research. 52(1), 1-14.

Yoo, B., Donthu, N. and Lee, S. (2000). "An Examination of Selected Marketing Mix Elements and Brand Equity". Journal of the Academy of Marketing Science, 28(2), 195-211.

Zeithaml, V. A. (1988). "Consumer perceptions of price, quality, and value: a mean-end model and synthesis of evidence", J. of Marketing Res. 2-22. 